\title{
Peramalan Kecepatan Angin Di Kota Pekanbaru Menggunakan Metode Box-Jenkins
}

\author{
Ari Pani Desvina ${ }^{1}$, Melina Anggriani ${ }^{2}$ \\ , 2 Jurusan Matematika, Fakultas Sains dan Teknologi, UIN Sultan Syarif Kasim Riau \\ Jl. HR. Soebrantas No. 155 Simpang Baru, Panam, Pekanbaru, 28293 \\ E-mail: Aripanidesvina@gmail.com@uin-suska.ac.id,melinaanggriani@yahoo.co.id@uin-suska.ac.id.
}

\begin{abstract}
ABSTRAK
Penelitian ini membahas tentang model peramalan kecepatan angin di Kota Pekanbaru menggunakan metode Box-Jenkins. Data yang digunakan adalah data kecepatan angin yang diambil dari Januari 2009 sampai September 2014 di Badan Meteorologi, Klimatologi,dan Geofisika (BMKG) Kota Pekanbaru. Hasil yang diperoleh menunjukan bahwa model ARIMA $(1,1,1)$ adalah model yang sesuai untuk meramalkan kecepatan angin. Hasil peramalan menunjukkan bahwa data kecepatan angin untuk tahun 2015 mengalami peningkatan dan penurunan pada waktu tertentu.
\end{abstract}

Katakunci: ARIMA, Box-Jenkins, Kecepatan Angin.

\section{ABSTRACT}

This research is about the wind speed forecasting model in Pekanbaru by using Box-Jenkins method. The data used is the wind speed data taken from January 2009 to September 2014. The results obtained show that the ARIMA $(1,1,1)$ model is an appropriate model to predict wind speed. Forecasting results indicate that wind speed data for 2015 have increased and decreased at a certain time.

Keywords: ARIMA, Box-Jenkins, Wind Speed.

\section{Pendahuluan}

Setiap makluk yang hidup di permukaan bumi ini pasti membutuhkan udara, baik manusia, hewan, dan tumbuhan. Lapisan udara di permukaan bumi disebut atmosfer, yang dibagi menjadi beberapa macam, yaitu: nitrogen sebesar $78 \%$, oksigen $21 \%$, serta $1 \%$ berupa uap air, karbon dioksida, dan gas-gas lain. Oksigen adalah udara yang sehari-hari kita hirup dan dibutuhkan oleh tubuh manusia dari berbagai jenis udara yang terdapat di atmosfer. Nitrogen bagi tumbuhan membantu mempercepat pertumbuhan tanaman, meningkatkan produksi bibit dan buah, serta memperbaiki kualitas daun dan akar.

Selain itu, udara yang bergerak, atau biasa kita sebut dengan angin, juga memiliki peranan yang besar bagi kehidupan manusia. Bangsa-bangsa Barat yang datang ke Indonesia pada masa lampau menggunakan kapal-kapal yang digerakkan oleh tenaga angin. Angin juga dapat digunakan sebagai sumber energi, caranya yaitu dengan mengubah energi gerak angin menjadi energi listrik. Angin juga dimanfaatkan oleh manusia sebagai sarana rekreasi dan olahraga, seperti: terjun payung, gantole, terbang layang, dan main layanglayangan.

Sebaliknya, kecepatan angin dalam kisaran tertentu (melebihi batas maksimum kondisi aman) juga dapat menimbulkan kerugian bagi manusia. Kecepatan angin yang melebihi $40 \mathrm{~km} / \mathrm{jam}$ dapat menyebabkan bencana yang tentunya akan sangat merugikan manusia, misalnya rusaknya bangunan akibat badai, tanaman rusak, nelayan tidak dapat melaut akibat gelombang laut meninggi dan lain-lain.

Ditinjau dari segi perekonomian, sebagian masyarakat Kota Pekanbaru bergantung dari hasil pertanian. Angin dalam budidaya pertanian dapat berpengaruh langsung seperti merobohkan tanaman. Namun pengaruh angin secara tidak langsung sangat kompleks baik yang menguntungkan maupun merugikan bagi tanaman. Dengan adanya angin maka akan membantu dalam penyerbukan tanaman dan pembenihan alamiah. Namun kelemahannya juga akan terjadi penyerbukan silang dan penyebaran benih gulma yang tidak dikehendaki. Selain itu, angin merupakan salah satu penyebar hama dan patogen yang dapat mempertinggi serangan hama 
dan penyakit yang akan sangat merugikan. Pentingnya meramalkan kecepatan angin untuk menghindari timbulnya kerugian bagi kehidupan manusia inilah yang menjadi latar belakang dari adanya penelitian ini, terutama bagi kota besar seperti Kota Pekanbaru.

Beberapa penelitian mengenai peramalan kecepatan angin telah dilakukan sebelumnya, antara lain oleh Irhamah, dkk (2010), dan Faulina (2010). Perbedaan yang mendasar pada penelitian sebelumnya dengan penelitian ini adalah pada metode taksiran yang digunakan. Dalam tugas akhir ini penulis menggunakan metode Box-Jenkins. Metode Box-Jenkins adalah metode peramalan pada model time series . Teknik dalam penggunaan Box-Jenkins berbeda dengan kebanyakan model peramalan yang ada, karena model yang dipilih akan dicek ulang dengan data historis apakah telah menggambarkan data yang tepat. Metode Box-Jenkins terdiri dari beberapa model yaitu Autoregressive (AR), Moving Average (MA), Autoregressive Moving Average (ARMA) dan Autoregressive Integrated Moving Average (ARIMA). Pekanbaru.

Pada penelitian ini mengemukakan tentang bagaimana menentukan peramalan kecepatan angin di Kota

Dalam penelitian ini bertujuan untuk mendapatkan hasil peramalan kecepatan angin di Kota Pekanbaru Menggunakan metode Box-Jenkins.

\section{Metode Penelitian}

Metode analisis data yang digunakan dalam penelitian ini adalah menggunakan metode Box-Jenkins. Adapun langkah-langkah yang digunakan untuk menganalisa data sebagai berikut:

\section{Jenis dan Sumber Data}

a. Jenis Data

Data yang digunakan dalam penelitian ini adalah data kecepatan angin dari Januari 2009 sampai September 2014.

b. Sumber Data

Data diperoleh dari Badang Meteorologi, Klimatologi dan Geofisika (BMKG) Kota Pekanbaru.

\section{Metode Analisis Data}

Langkah-langkah yang digunakan dalam penelitian ini adalah sebagai berikut :

Langkah

: Mengumpulkan data, kemudian data diorganisir dan data siap untuk dianalisis

Langkah 2

: Identifikasi Model

Langkah 3

: Uji kestasioneran Data

Langkah 4

Langkah 5

: Estimasi Parameter

Langkah 6

: Uji Kesesuaian Model

: Peramalan

Jalannya penelitian dapat ditunjukkan pada Gambar 1 dibawah ini: 


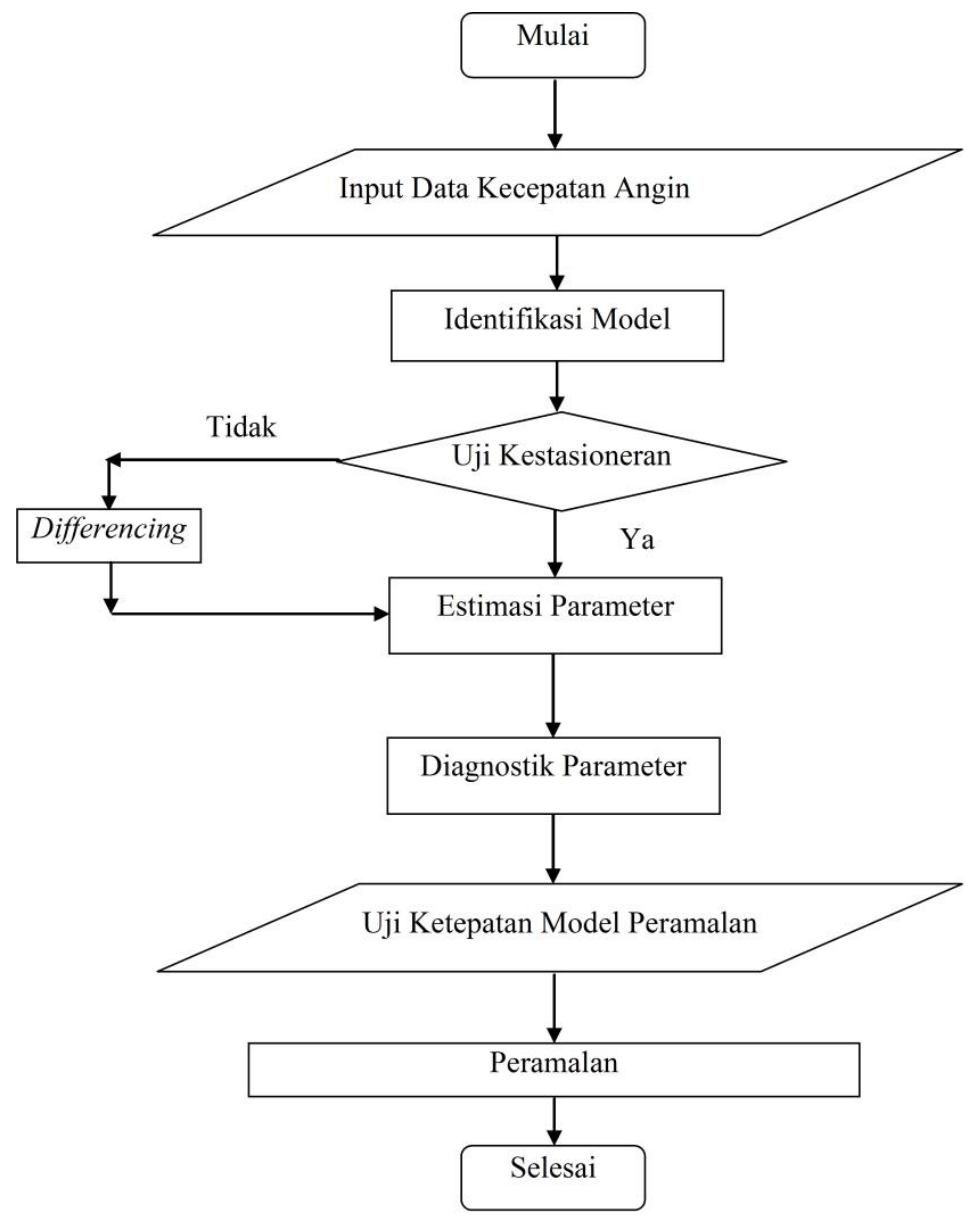

Gambar 1 Flowchart Metodologi Penelitian

\section{Hasil dan Pembahasan}

Kecepatan angin di Kota Pekanbaru mengalami perubahan setiap bulannya. Rata-rata kecepatan angin perbulan dapat digambarkan pada histogram sebagai berikut:

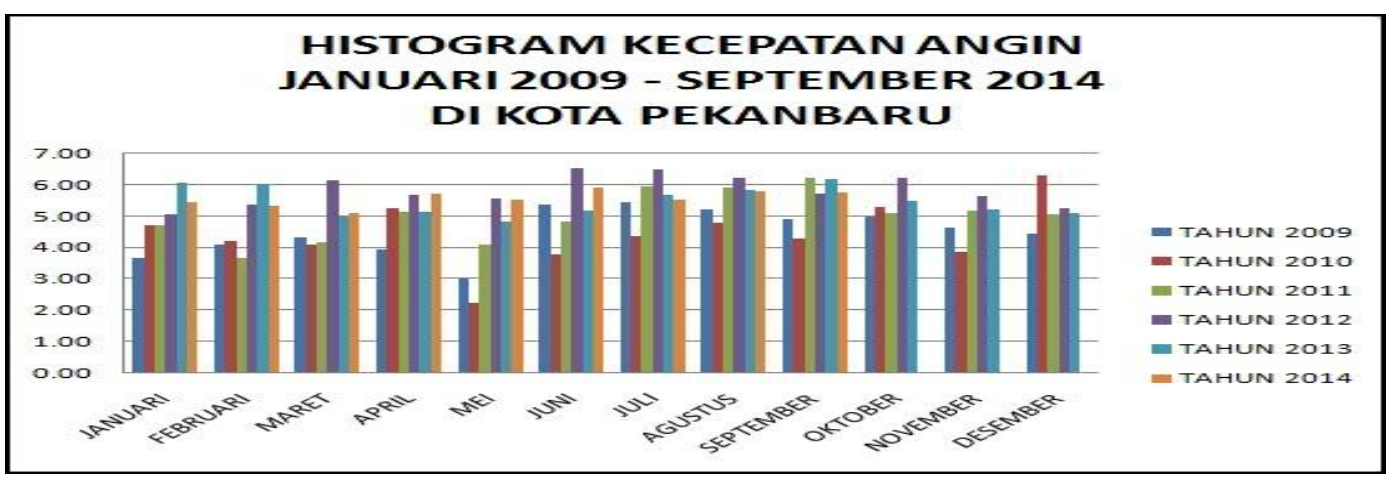

Gambar 2 Histogram Kecepatan Angin

Berdasarkan Gambar 2 dapat dilihat bahwa kecepatan angin di Kota Pekanbaru mengalami perubahan setiap bulannya. Kecepatan angin yang terbesar terjadi pada Juni 2012 yaitu sebesar 6,53 knot dan yang terkecil terjadi pada Mei 2010 yaitu sebesar 2,25 knot. Perubahan kecepatan angin disebabkan oleh besar kecilnya gradien barometrik, ketinggian angin bertiup dari muka bumi, relief bumi, dan ada tidaknya vegetasi. Besar kecilnya gradient barometrik yang dimaksud adalah kekuatan angin berbanding lurus dengan gradien barometer.Sementara itu, kekuatan angin ditentukan oleh kecepatannya. Semakin cepat angin 
bertiup, semakin besar kekuatannya. Berikut adalah statistik deskriptif kecepatan angin yang disajikan dalam Tabel 1.

Tabel 1 Statistik Deskriptif Kecepatan Angin

\begin{tabular}{|c|c|c|c|c|}
\hline Variabel & $\mathrm{N}$ & Minimum & Maksimum & Rata-rata \\
\hline Kecepatan Angin & 69 & 2,25 & 6,53 & 5,12 \\
\hline
\end{tabular}

Berdasarkan Tabel 1 dapat dilihat bahwa rata-rata perbulan kecepatan angin adalah 5.12 knot dengan kecepatan angin minimum adalah 2,25 knot dan maksimumnya adalah 6,53 knot.

\section{Pembentukan Model Peramalan Kecepatan Angin} Langkah 1. Identifikasi Model

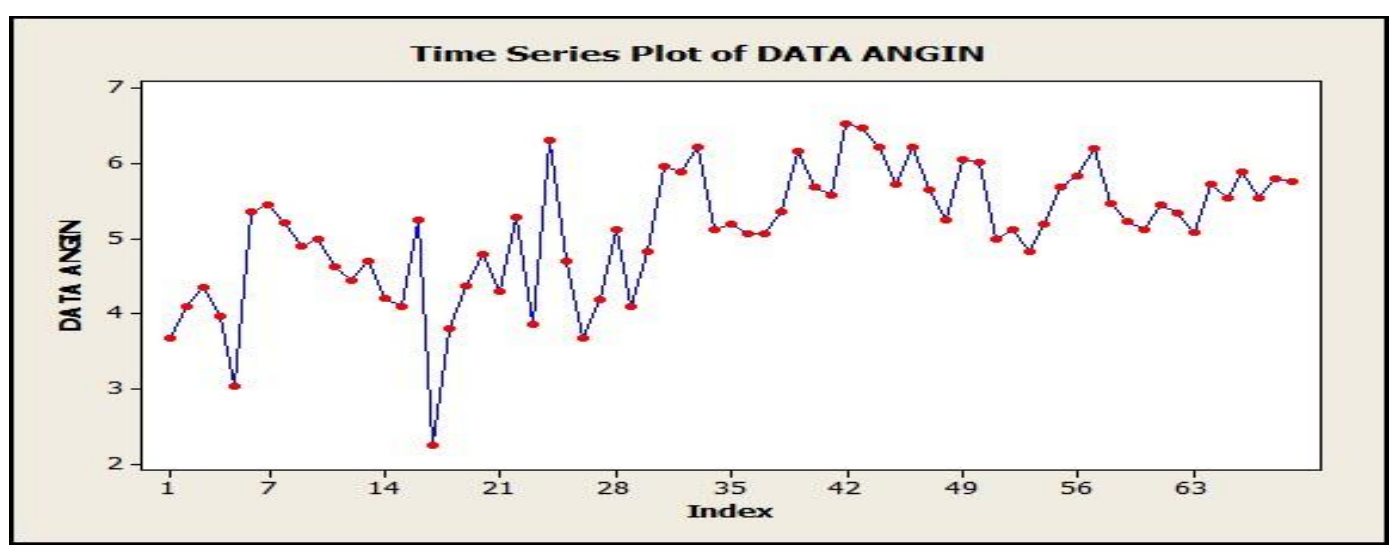

Gambar 3 Grafik Data Aktual Kecepatan Angin

Berdasarkan Gambar 3 dapat dilihat secara kasat mata bahwa data tidak stasioner.

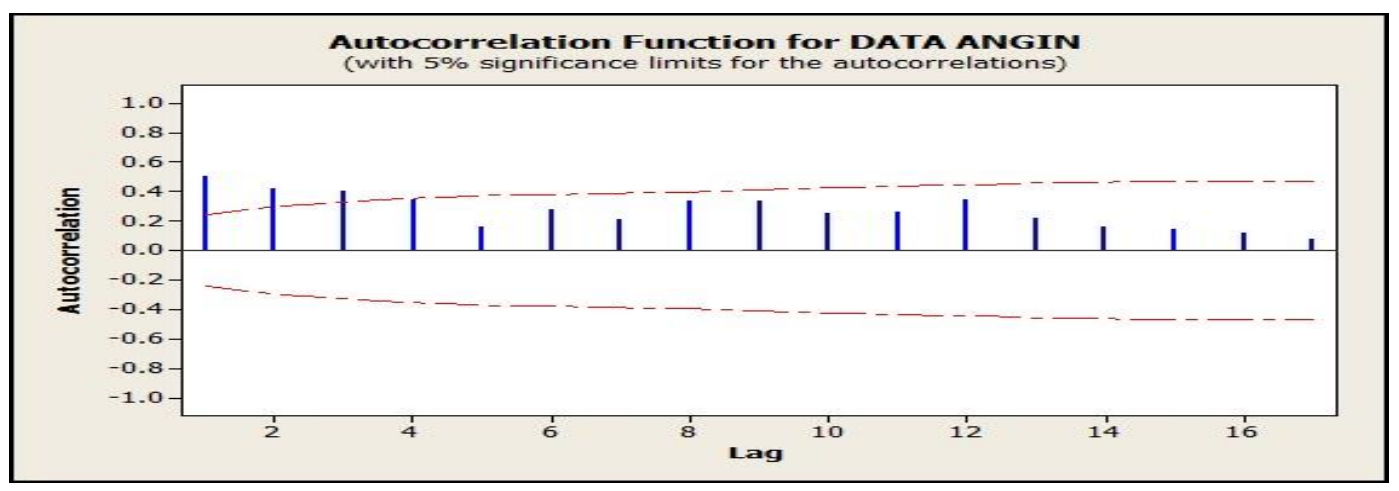

Gambar 4 Grafik ACF Data Aktual

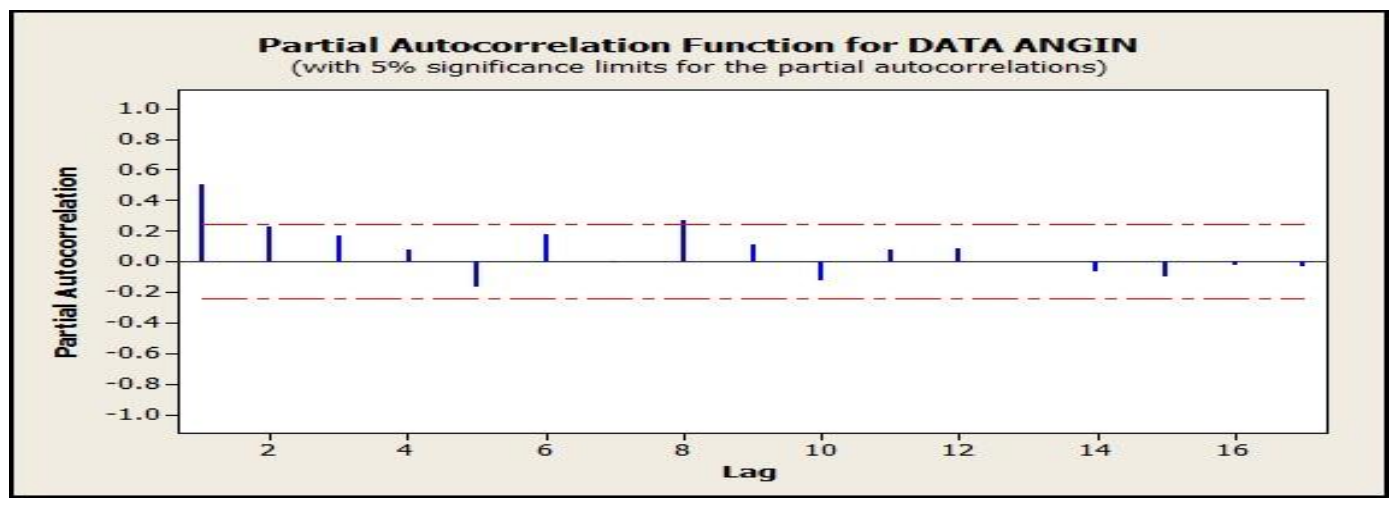

Gambar 5 Grafik PACF Data Aktual 
Berdasarkan Gambar 4 dan 5 dapat dilihat bahwa lag-lag pada grafik autokorelasi tidak turun secara eksponen. Sehingga dapat disimpulkan bahwa data tidak stasioner karena adanya unsur tren naik. Untuk menghilangkan unsur tren pada data dapat dilakukan dengan differencing non musiman orde satu.

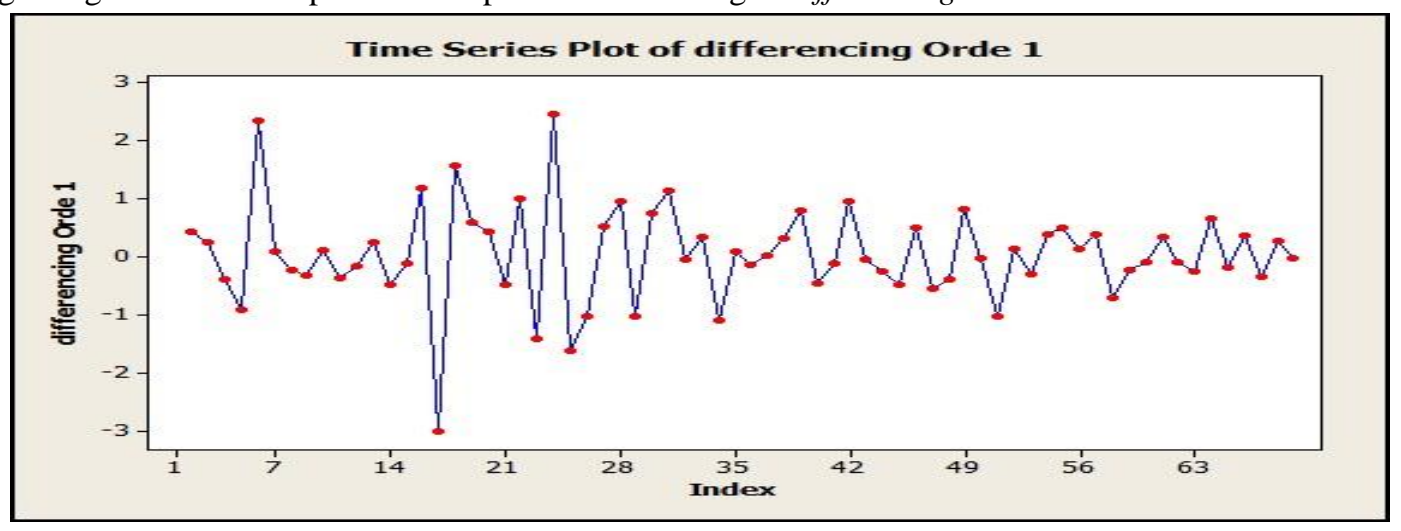

Gambar 6 Grafik Data Hasil Differencing Non Musiman Orde Satu

Berdasarkan Gambar 6 dapat dilihat bahwa data sudah tidak mengandung unsur tren naik.

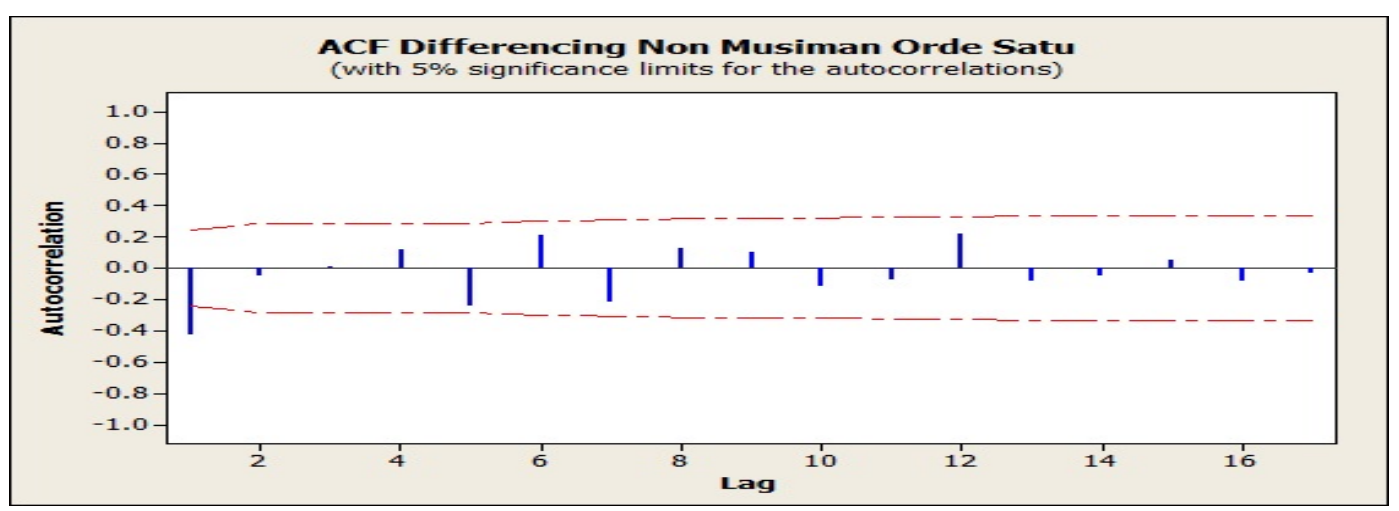

Gambar 7 Grafik ACF Differencing Non Musiman Orde Satu

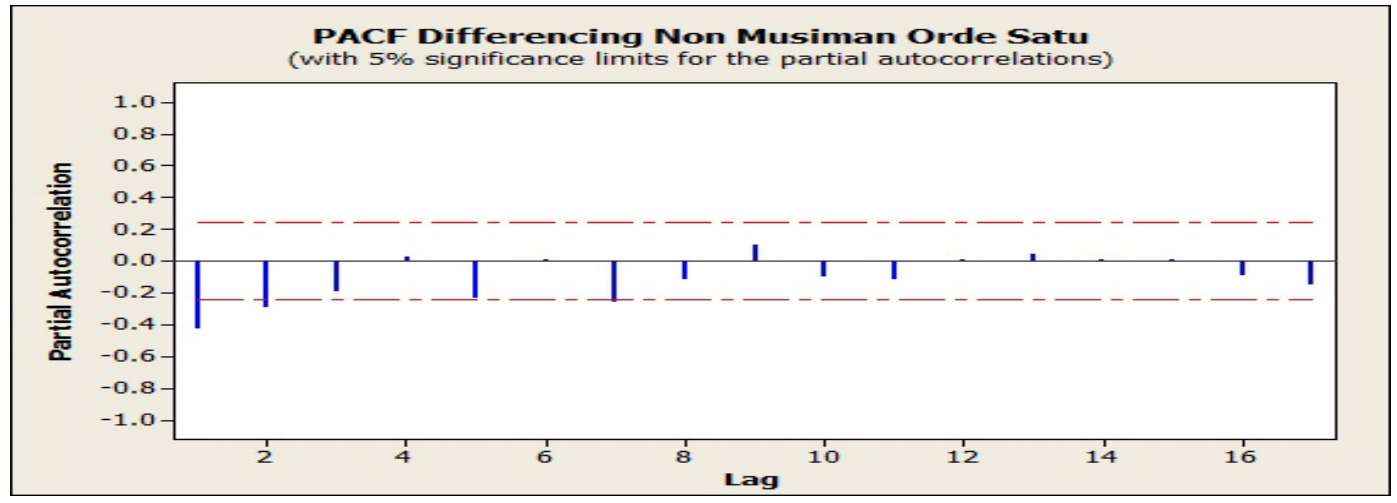

Gambar 8 Grafik PACF Differencing Non Musiman Orde Satu

Berdasarkan Gambar 7 dan 8 dapat dilihat bahwa data sudah stasioner dari unsur tren karena lag-lag pada grafik ACF dan PACF hasil differencing non musiman sudah turun secara eksponensial. Lag-lag pada grafik PACF turun secara eksponensial dan ACF terpangkas setelah lag 1, sehingga model sementara yang diperoleh berdasarkan differencing non musiman orde satuuntuk meramalkan kecepatan angin di Kota Pekanbaru adalah :

1. ARIMA $(1,1,1)$

Model matematisnya adalah sebagai berikut :

$X_{t}=\delta+e_{t}+\left(1+\phi_{1}\right) X_{t-1}-\phi_{1} X_{t-2}-\theta_{1} e_{t-1}$ 
2. $\quad$ ARIMA $(0,1,1)$

Model matematisnya adalah sebagai berikut :

$X_{t}=\delta+e_{t}+X_{t-1}-\theta_{1} e_{t-1}$

3. ARIMA $(1,1,0)$

Model matematisnya adalah sebagai berikut :

$X_{t}=\delta+e_{t}+\left(1+\phi_{1}\right) X_{t-1}-\phi_{1} X_{t-2}$

4. $\quad$ ARIMA $(2,1,1)$

Model matematisnya adalah sebagai berikut :

$X_{t}=\delta+e_{t}+\left(1+\phi_{1}\right) X_{t-1}-\left(\phi_{1}-\phi_{2}\right) X_{t-2}-\phi_{2} X_{t-3}-\theta_{1} e_{t-1}$

5. ARIMA $(2,1,0)$

Model matematisnya adalah sebagai berikut :

$X_{t}=\delta+e_{t}+\left(1+\phi_{1}\right) X_{t-1}-\left(\phi_{1}-\phi_{2}\right) X_{t-2}-\phi_{2} X_{t-3}$

Langkah 2. Estimasi Parameter Model

1. Estimasi Parameter Model ARIMA $(1,1,1)$

Tabel 2 Estimasi Parameter Model ARIMA $(1,1,1)$

\begin{tabular}{|c|c|c|}
\hline Parameter & Koefisien & P-value \\
\hline$\phi_{1}$ & 0,2926 & 0,018 \\
\hline$\theta_{1}$ & 1,0293 & 0,000 \\
\hline$\delta$ & 0,014980 & 0,000 \\
\hline
\end{tabular}

Langkah selanjutnya adalah melakukan uji signifikansi terhadap parameter model dengan cara membandingkan nilai $P$-value pada setiap parameter model dengan level toleransi $\alpha$, dengan hipotesis:

$H_{0}$ : Parameter model tidak signifikan dalam model

$H_{1}$ : Parameter model signifikan dalam model

Berdasarkan hasil yang diperoleh pada tahap penaksiran parameter, maka parameter yang signifikan dalam model adalah $\phi_{1}=0,2926, \theta_{1}=1,0293$ dan $\delta=0,014980$. Sehingga bentuk matematis dari model tersebut dapat dirumuskan kembali sebagai berikut:

$X_{t}=0,014980+e_{t}+1,2926 X_{t-1}-0,2926 X_{t-2}-1,0293 e_{t-1}$

2. Estimasi Parameter Model ARIMA $(0,1,1)$

Tabel 3 Estimasi Parameter Model ARIMA $(0,1,1)$

\begin{tabular}{|c|c|c|}
\hline Parameter & Koefisien & P-value \\
\hline$\theta_{1}$ & 0,7905 & 0,000 \\
\hline$\delta$ & 0,02350 & 0,198 \\
\hline
\end{tabular}

Berdasarkan hasil yang diperoleh pada tahap penaksiran parameter, maka parameter yang signifikan dalam model adalah $\theta_{1}=0,7905$. Sehingga bentuk matematis dari model tersebut dapat dirumuskan kembali sebagai berikut:

$X_{t}=e_{t}+X_{t-1}-0,7905 e_{t-1}$

3. Estimasi Parameter Model ARIMA $(1,1,0)$

Tabel 4 Estimasi Parameter Model ARIMA $(1,1,0)$

\begin{tabular}{|c|c|c|}
\hline Parameter & Koefisien & P-value \\
\hline$\phi_{1}$ & $-0,4314$ & 0,000 \\
\hline$\delta$ & 0,04189 & 0,648 \\
\hline
\end{tabular}

Berdasarkan hasil yang diperoleh pada tahap penaksiran parameter, maka parameter yang signifikan dalam model adalah $\phi_{1}=-0,4314$. Sehingga bentuk matematis dari model tersebut dapat dirumuskan kembali sebagai berikut:

$X_{t}=e_{t}+0,5686 X_{t-1}+0,4314 X_{t-2}$ 
4. Estimasi Parameter Model ARIMA $(2,1,1)$

Tabel 5 Estimasi Parameter Model ARIMA $(2,1,1)$

\begin{tabular}{|c|c|c|}
\hline Parameter & Koefisien & P-value \\
\hline$\phi_{1}$ & $-1,2636$ & 0,000 \\
\hline$\phi_{2}$ & $-0,2641$ & 0,028 \\
\hline$\theta_{1}$ & $-1,0171$ & 0,000 \\
\hline$\delta$ & 0,1106 & 0,539 \\
\hline
\end{tabular}

Berdasarkan hasil yang diperoleh pada tahap penaksiran parameter, maka parameter yang signifikan dalam model adalah $\phi_{1}=-1,2636, \phi_{2}=-0,2641$ dan $\theta_{1}=0,1106$. Sehingga bentuk matematis dari model tersebut dapat dirumuskan kembali sebagai berikut:

$X_{t}=e_{t}-0,2636 X_{t-1}+0,9995 X_{t-2}+0,2641 X_{t-3}-0,1106 e_{t-1}$

5. Estimasi Parameter Model ARIMA $(2,1,0)$

Tabel 6 Estimasi Parameter Model ARIMA $(2,1,0)$

\begin{tabular}{|c|c|c|}
\hline Parameter & Koefisien & P-value \\
\hline$\phi_{1}$ & $-0,5587$ & 0,000 \\
\hline$\phi_{2}$ & $-0,2938$ & 0,016 \\
\hline$\delta$ & 0,05077 & 0,565 \\
\hline
\end{tabular}

Berdasarkan hasil yang diperoleh pada tahap penaksiran parameter, maka parameter yang signifikan dalam model adalah $\phi_{1}=-0,5587$ dan $\phi_{2}=-0,2938$. Sehingga bentuk matematis dari model tersebut dapat dirumuskan kembali sebagai berikut:

$X_{t}=\delta+e_{t}+0,4413 X_{t-1}+0,2649 X_{t-2}+0,2938 X_{t-3}$

\section{Langkah 3. Pemeriksaan Diagnostik}

a. Uji Independensi Residual

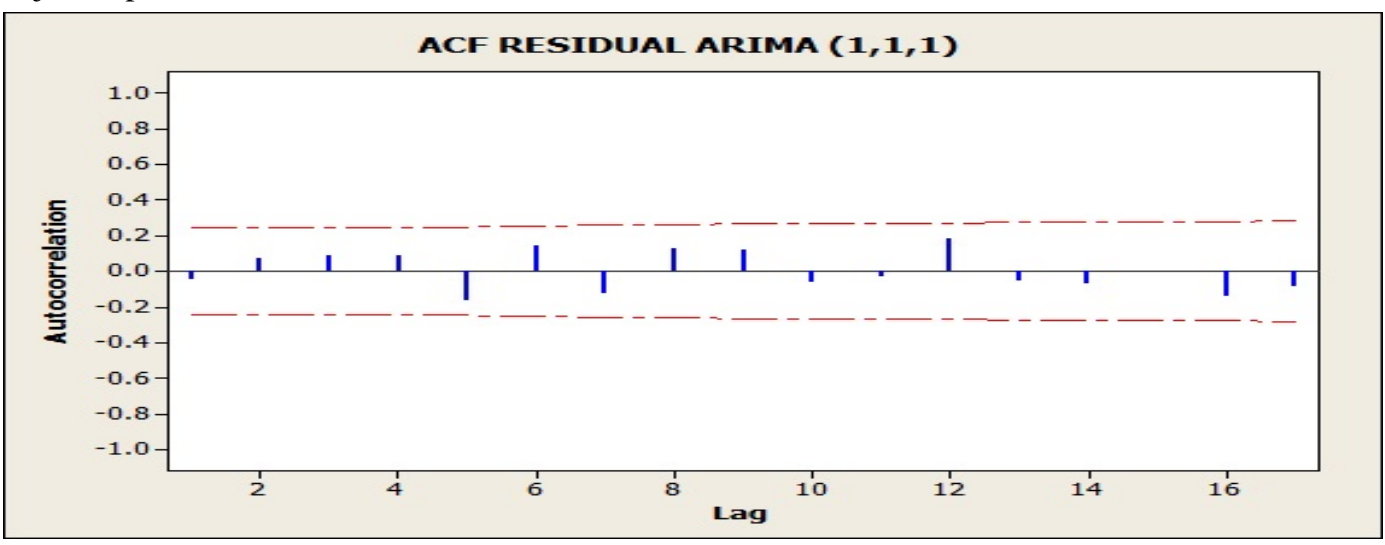

Gambar 9 ACF Residual Model ARIMA(1, 1, 1)

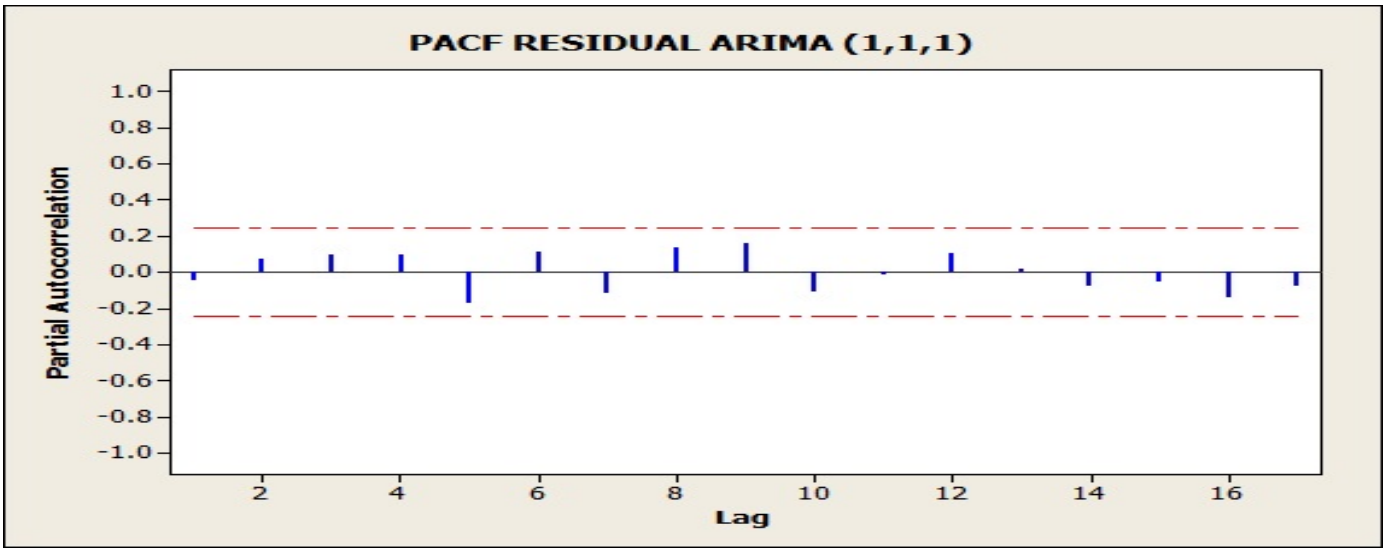

Gambar 10 PACF Residual Model ARIMA(1, 1, 1) 
Berdasarkan Gambar 9 dan 10 dapat dilihat bahwa tidak terdapat lag yang memotong garis batas atas dan batas bawah korelasi residual, sehingga dapat disimpulkan bahwa residual yang dihasilkan model tidak berkorelasi.

Tabel 7 Output Ljung-Box Model ARIMA $(1,1,1)$

\begin{tabular}{|c|c|c|c|c|}
\hline Lag & 12 & 24 & 36 & 48 \\
\hline P-value & 0,207 & 0,316 & 0,450 & 0,794 \\
\hline
\end{tabular}

Berdasarkan Tabel 7 dapat dilihat bahwa nilai $P$-value untuk setiap lag lebih besar dari selang kepercayaan 5\% yaitu $P-$ value $>\propto$. Sehingga dapat disimpulkan bahwa residual model mengikuti proses random.

2. Uji Independensi Residual Model ARIMA $(0,1,1)$

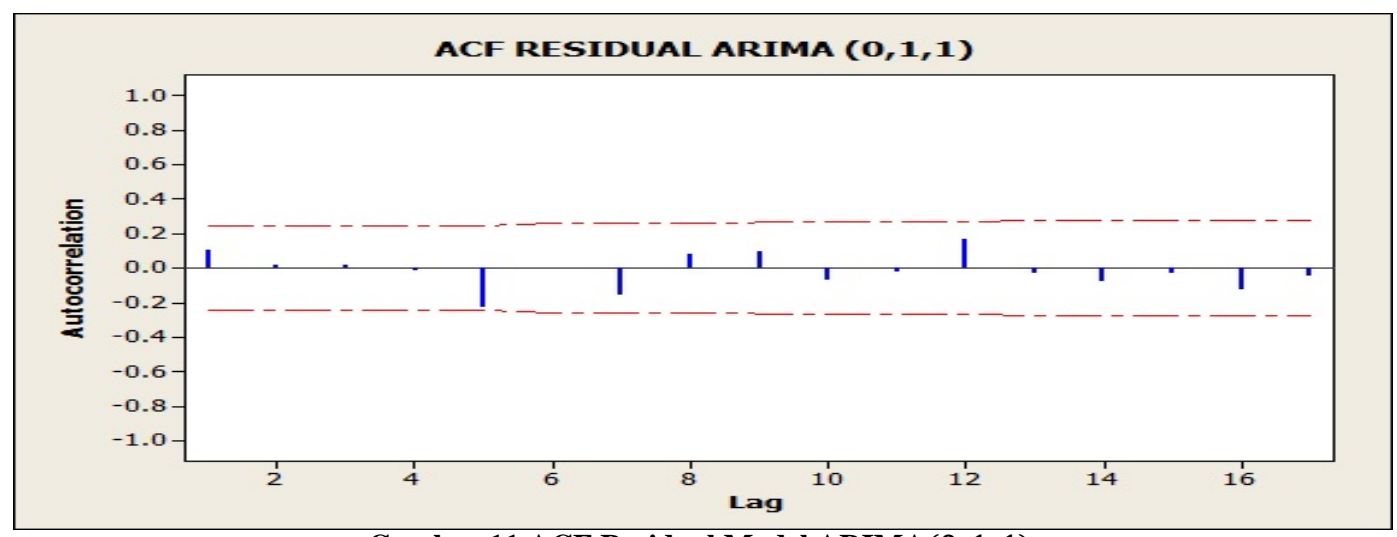

Gambar 11 ACF Residual Model ARIMA(0, 1, 1)

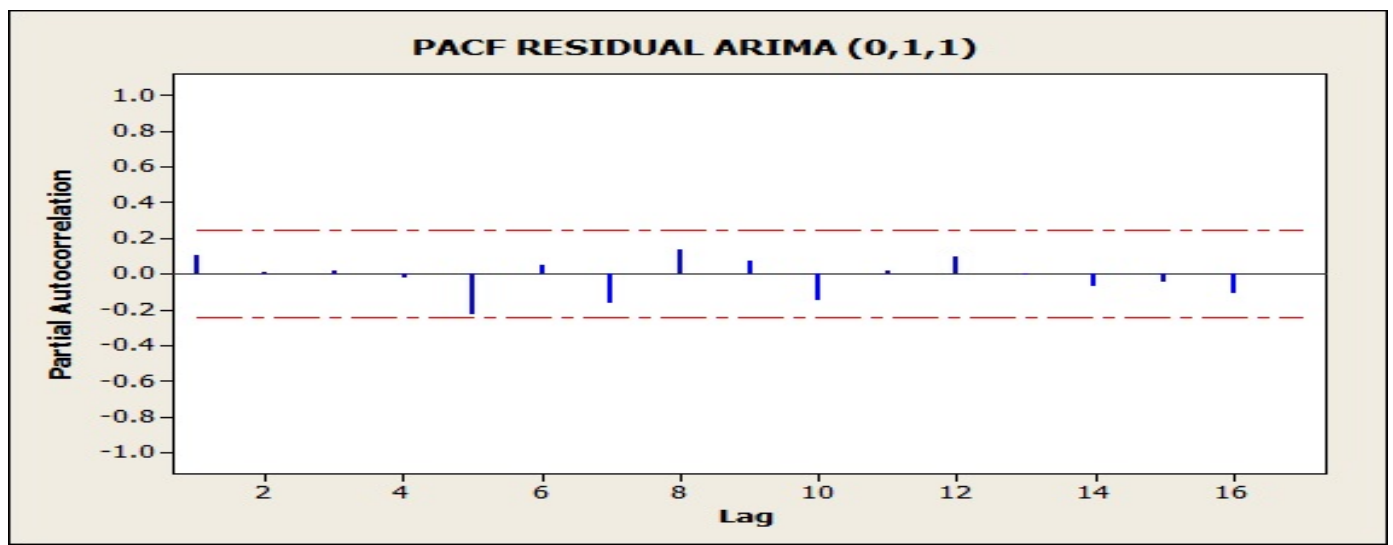

Gambar 12 PACF Residual Model ARIMA $(0,1,1)$

Berdasarkan Gambar 11 dan 12 dapat dilihat bahwa tidak terdapat lag yang memotong garis batas atas dan batas bawah korelasi residual, sehingga dapat disimpulkan bahwa residual yang dihasilkan model tidak berkorelasi.

Tabel 8 Output Ljung-Box Model ARIMA $(0,1,1)$

\begin{tabular}{|c|c|c|c|c|}
\hline Lag & 12 & 24 & 36 & 48 \\
\hline P-value & 0,364 & 0,507 & 0,323 & 0,671 \\
\hline
\end{tabular}

Berdasarkan Tabel 8 dapat dilihat bahwa nilai $P$ - value untuk setiap lag lebih besar dari selang kepercayaan 5\% yaitu $P-$ value $>\propto$. Sehingga dapat disimpulkan bahwa residual model mengikuti proses random. 
3. Uji Independensi Residual Model ARIMA $(1,1,0)$

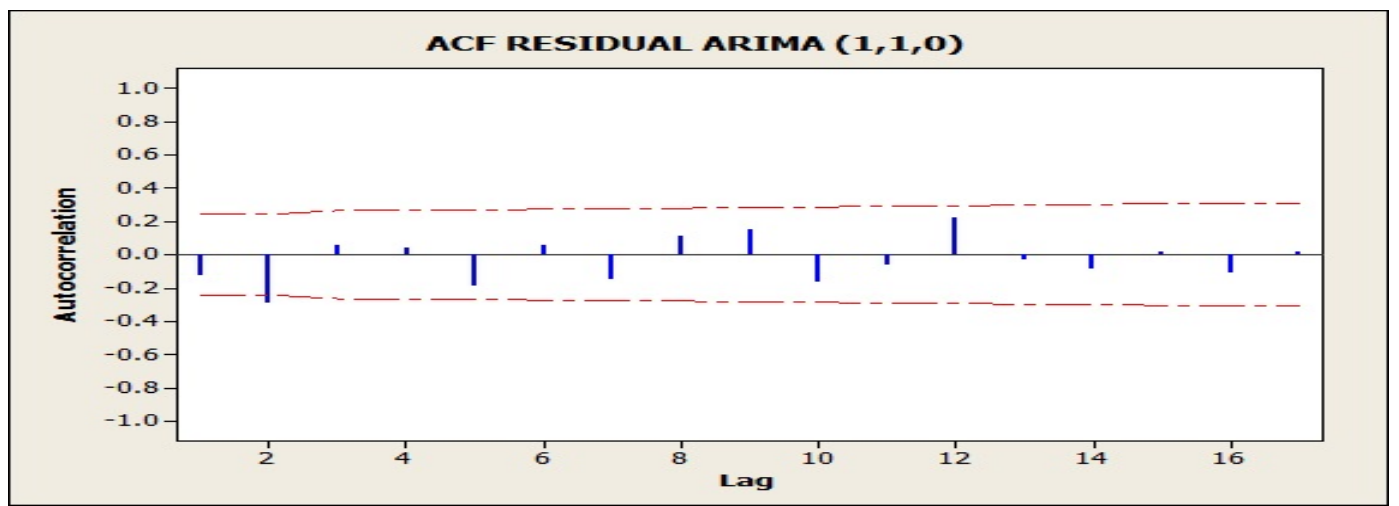

Gambar 13 ACF Residual Model ARIMA(1, 1, 0)

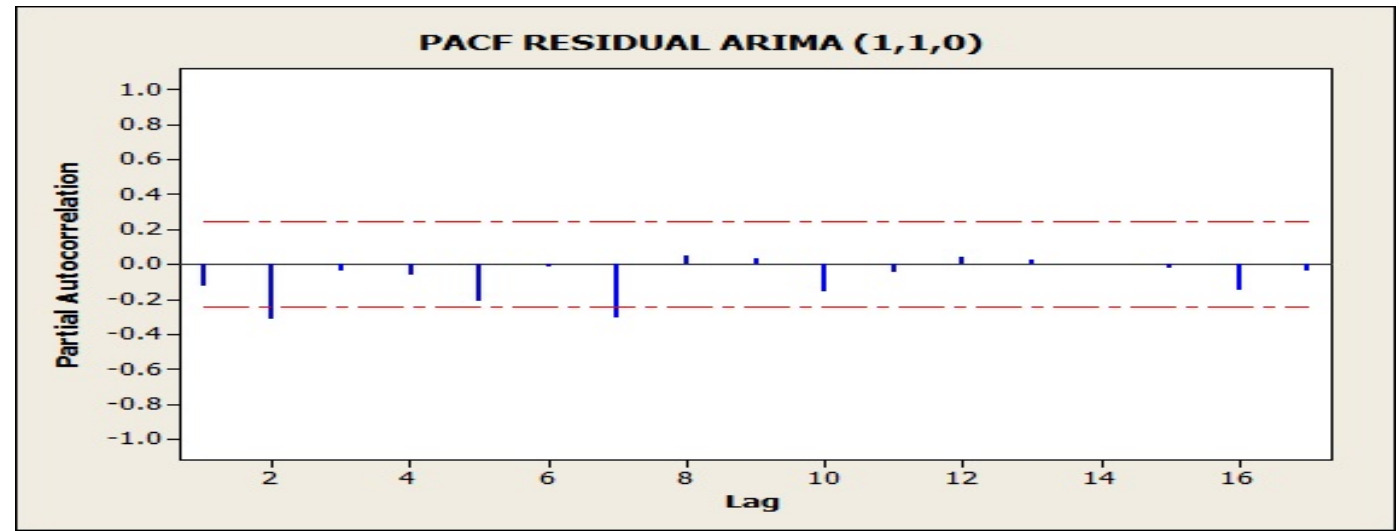

Gambar 14 PACF Residual Model ARIMA $(1,1,0)$

Berdasarkan Gambar 13 dan 14 dapat dilihat bahwa terdapat lag yang memotong garis batas atas dan batas bawah korelasi residual, sehingga dapat disimpulkan bahwa residual yang dihasilkan model berkorelasi.

Tabel 9 Output Ljung-Box Model ARIMA $(1,1,0)$

\begin{tabular}{|c|c|c|c|c|}
\hline Lag & 12 & 24 & 36 & 48 \\
\hline P-value & 0,016 & 0,043 & 0,133 & 0,380 \\
\hline
\end{tabular}

Berdasarkan Tabel 9 dapat dilihat bahwa hanya lag 36 dan 48 yang memiliki nilai $P$ - value yang lebih besar dari selang kepercayaan $5 \%$ atau $P$ - value $>\propto$. Sehingga dapat disimpulkan bahwa model tidak layak digunakan. 
4. Uji Independensi Residual Model $\operatorname{ARIMA}(2,1,1)$

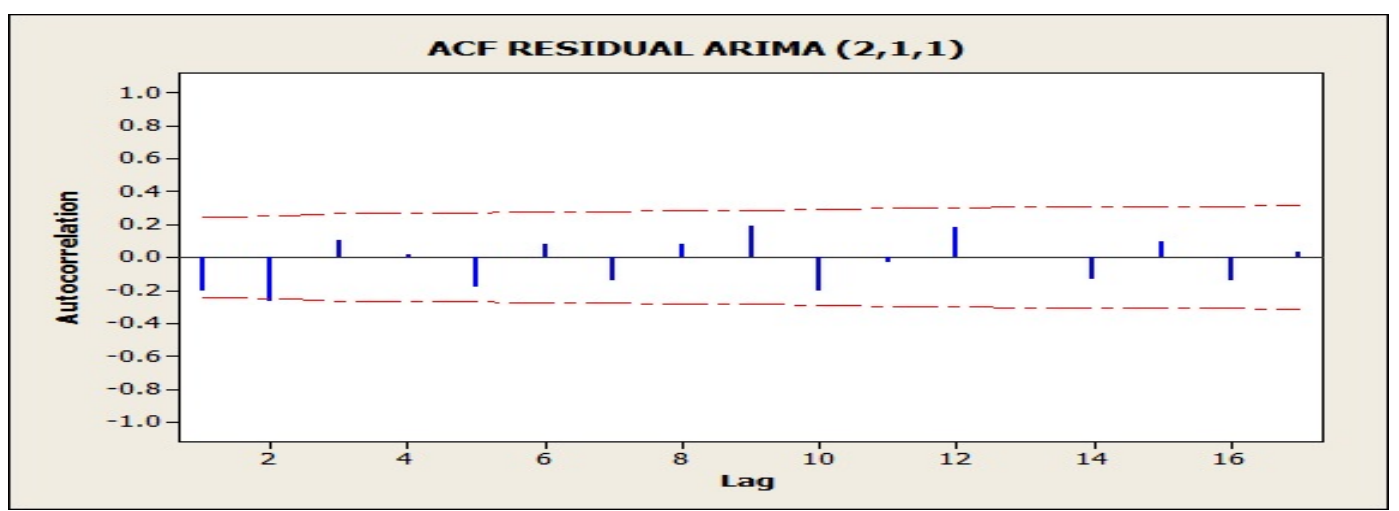

Gambar 15 ACF Residual Model ARIMA(2, 1, 1)

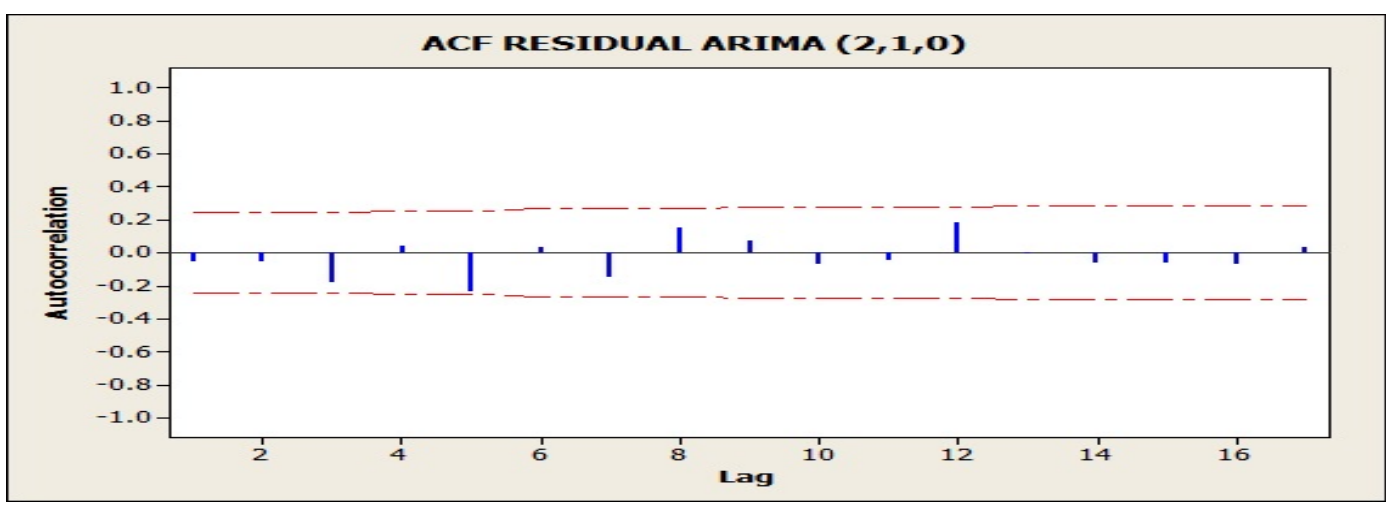

Gambar 16 PACF Residual Model ARIMA $(2,1,1)$

Berdasarkan Gambar 15dan 16 dapat dilihat terdapat lag yang memotong garis batas atas dan batas bawah korelasi residual, sehingga dapat disimpulkan bahwa residual yang dihasilkan model berkorelasi.

Tabel 10 Output Ljung-Box Model ARIMA(2, 1, 1)

\begin{tabular}{|c|c|c|c|c|}
\hline Lag & 12 & 24 & 36 & 48 \\
\hline P-value & 0,004 & 0,015 & 0,070 & 0,240 \\
\hline
\end{tabular}

Berdasarkan Tabel 10 dapat dilihat bahwa hanya lag 48 yang memiliki nilai $P$ - valuelebih besar dari selang kepercayaan 5\% yaitu $P$-value $>\propto$. Sehingga dapat disimpulkan bahwa model tidak layak digunakan.

5. Uji Independensi Residual Model ARIMA $(2,1,0)$

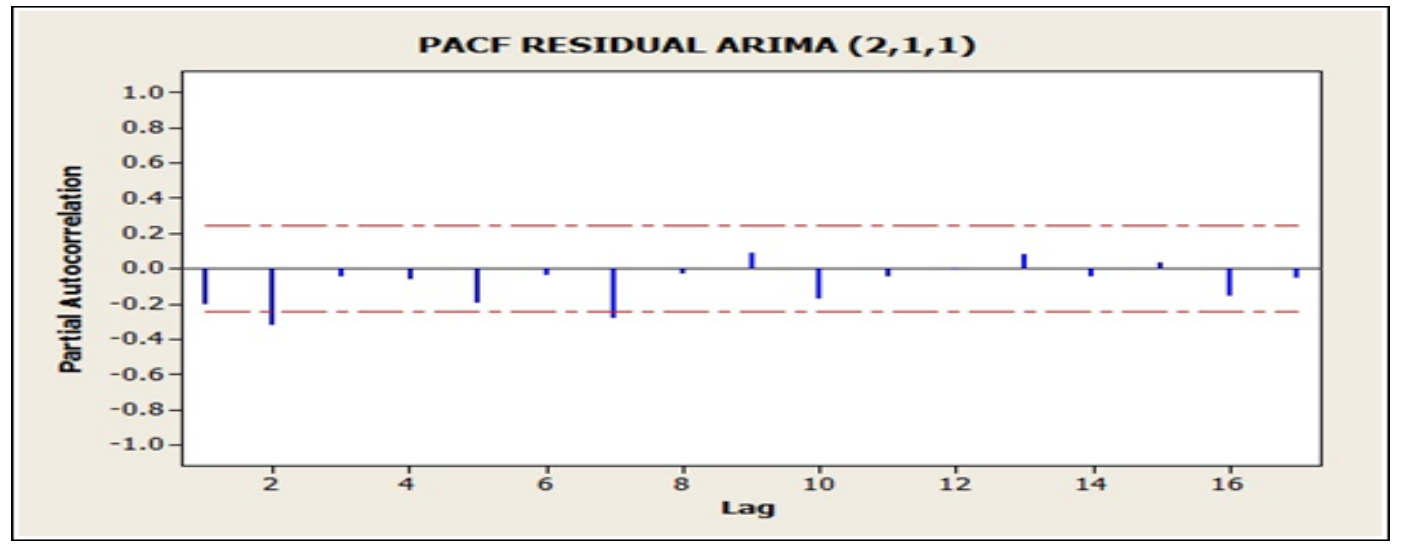

Gambar 17 ACF Residual Model ARIMA $(2,1,0)$ 


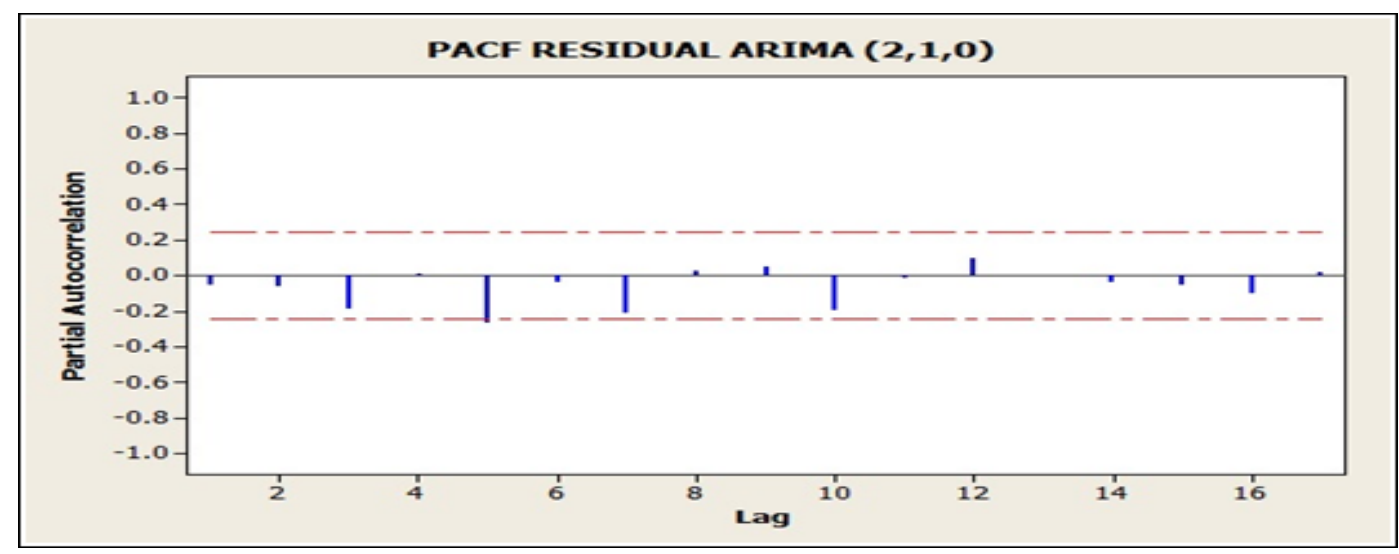

Gambar 18 PACF Residual Model ARIMA $(2,1,0)$

Berdasarkan Gambar 17 dan 18 dapat dilihat bahwa terdapat lag yang memotong garis batas atas dan batas bawah korelasi residual, sehingga dapat disimpulkan bahwa residual yang dihasilkan model berkorelasi.

Tabel 11 Output Ljung-Box Model ARIMA $(2,1,0)$

\begin{tabular}{|c|c|c|c|c|}
\hline Lag & 12 & 24 & 36 & 48 \\
\hline P-value & 0,011 & 0,042 & 0,172 & 0,312 \\
\hline
\end{tabular}

Berdasarkan Tabel 11 dapat dilihat bahwa hanya lag 36 dan lag 48 yang memiliki nilai $P$ - value lebih besar dari selang kepercayaan $5 \%$ yaitu $P-$ value $>\propto$. Sehingga dapat disimpulkan bahwa model tidak layak digunakan.

b. Uji Kenormalan Residual

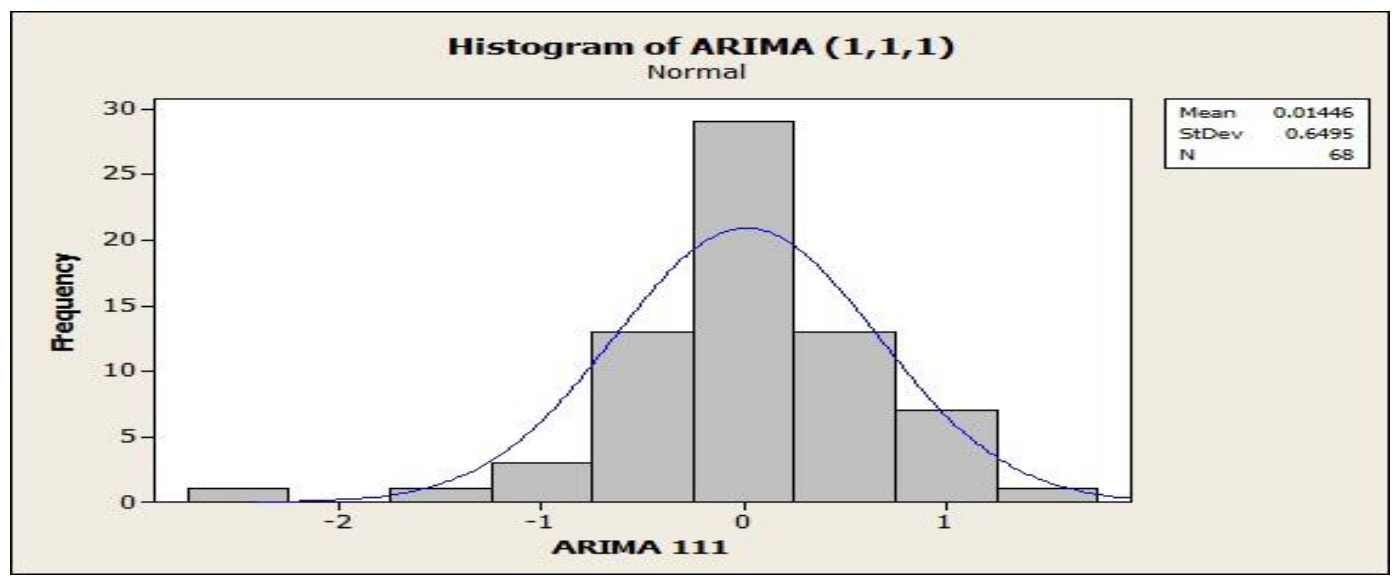

Gambar 19 Histogram Residual yang dihasilkan Model ARIMA(1, 1, 1)

Berdasarkan Gambar 4.18 dapat dilihat bahwa residual model telah mengikuti pola kurva normal, sehingga dapat disimpulkan bahwa residual model telah memenuhi asumsi kenormalan. 
Tabel 12 Uji Kolmogorov-Smirnov

\begin{tabular}{|ll|r|}
\hline \multicolumn{2}{|c|}{ One-Sample Kolmogorov-Smirnow Test } \\
\hline N & & RESIDUA.LAR \\
Norma111 & 68 \\
& Mean & .0145 \\
Most Extreme Differences & Absolute & .64952 \\
& Positive & .098 \\
& Negative & .068 \\
Kolmogorov-Smirnov $Z$ & & -.098 \\
Asymp. Sig. (2-tailed) & .805 \\
a. Test distribution is Normal. & .536 \\
\hline
\end{tabular}

Berdasarkan Tabel 12 dapat dilihat bahwa nilai signifikansi sebesar 0,536 lebih besar dari 0,05. Sehingga, dapat disimpulkan bahwa residual berdistribusi normal.

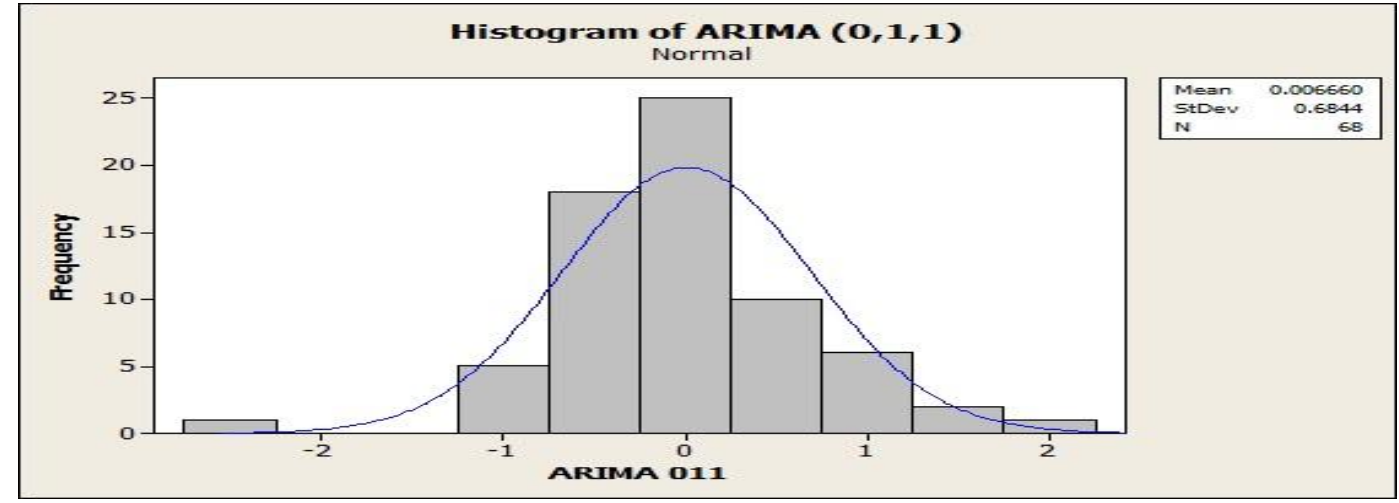

Gambar 20 Histogram Residual yang dihasilkan Model ARIMA(0, 1, 1)

Berdasarkan Gambar 20 dapat dilihat bahwa residual model telah mengikuti pola kurva normal, sehingga dapat disimpulkan bahwa residual model telah memenuhi asumsi kenormalan.

Tabel 13 Uji Kolmogorov-Smirnov

\begin{tabular}{|ll|r|}
\hline \multicolumn{3}{|c|}{ One-Sample Kolmogoron-Smirnow Test } \\
\hline N & RESIDUALAR \\
Normal Parameters & Mean & 68 \\
& Std. Deviation & .0067 \\
Most Extreme Differences & A.bsolute & .68442 \\
& Positive & .110 \\
Kolmogorov-Smirnov $Z$ & Negative & .110 \\
Asymp. Sig. (2-tailed) & & -.062 \\
a. Test distribution is Normal. & .911 \\
\hline
\end{tabular}

Berdasarkan Tabel 13 dapat dilihat bahwa nilai signifikansi sebesar 0,377 lebih besar dari 0,05. Sehingga, dapat disimpulkan bahwa residual berdistribusi normal. 
Berdasarkan uji yang dilakukan pada tahap pemeriksaan diagnostik maka model ARIMA $(1,1,1)$ dan $\operatorname{ARIMA}(0,1,1)$ layak digunakan untuk tahap peramalan. Untuk pemilihan model terbaik, maka dilihat dari Mean Square Error (MSE) yang terkecil dan diperoleh MSE untuk ARIMA $(0,1,1)$ adalah 0,461582 dan MSE untuk ARIMA $(1,1,1)$ adalah 0,415883.

\section{Langkah 4. Peramalan}

Untuk hasil peramalan yang lebih lengkap akan disajikan dalam Tabel 14 sebagai berikut:

Tabel 14 Hasil Peramalan Kecepatan Angin

\begin{tabular}{|c|c|c|}
\hline No & Bulan/Tahun & Kecepatan Angin \\
\hline 1 & Oktober 2014 & 6,14710 \\
\hline 2 & November 2014 & 6,17568 \\
\hline 3 & Desember 2014 & 6,23283 \\
\hline 4 & Januari 2015 & 6,26140 \\
\hline 5 & Februari 2015 & 6,28997 \\
\hline 6 & Maret 2015 & 6,31855 \\
\hline 7 & April 2015 & 6,34712 \\
\hline 8 & Mei 2015 & 6,37570 \\
\hline 9 & Juni 2015 & 6,40427 \\
\hline 10 & Juli 2015 & 6,43284 \\
\hline 11 & Agustus 2015 & 6,46142 \\
\hline 12 & September 2015 & \\
\hline
\end{tabular}

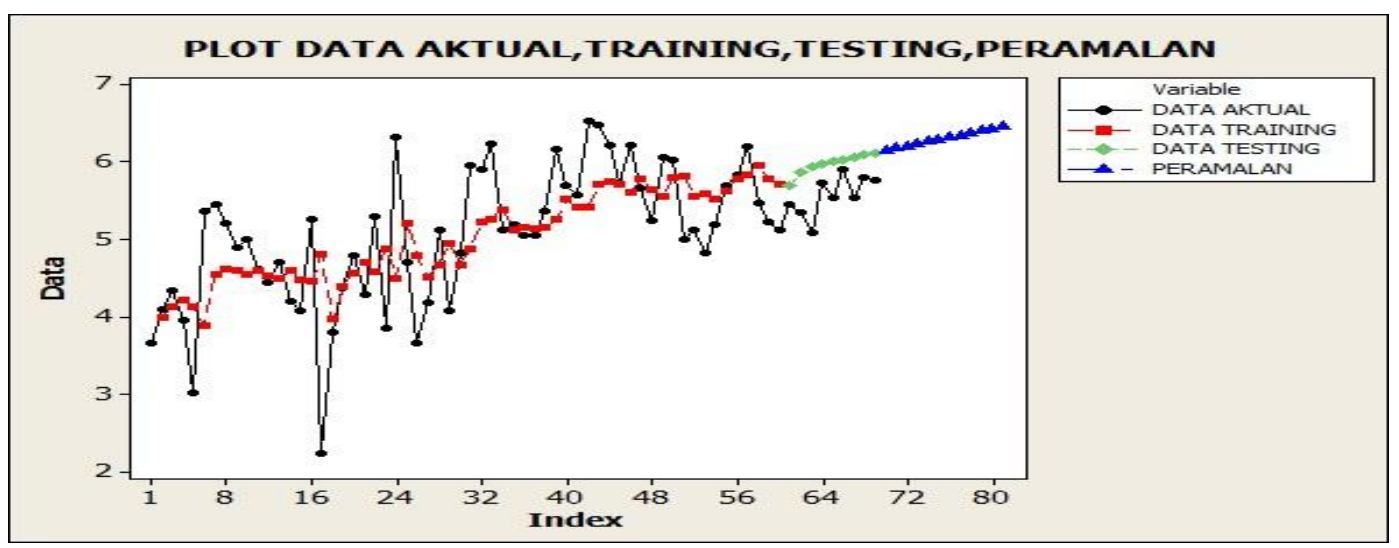

Gambar 21 Grafik Peramalan Training, Testing dan Peramalan Kecepatan Angin Tahun 2015 